\title{
Ultrasonographic evaluation of ventriculomegaly cases
}

\author{
Hakan Kalaycı, Halis Özdemir, Çağrı Gülümser, Ayşe Parlakgümüş, Tayfun Çok, Ebru Tarım, Filiz Bilgin Yanık \\ Department of Gynecology \& Obstetrics, Medical School of Başkent University, Ankara, Turkey
}

\begin{abstract}
Objective: To evaluate retrospectively the demographic data of the patients diagnosed in or referred with the pre-diagnosis of ventriculomegaly to Perinatology Department of Adana and Ankara Hospitals of Başkent University.

Methods: In this study, 61 pregnant women with fetal ventriculomegaly diagnosed in our clinic or referred by other centers to the Perinatology Department of Ankara and Adana Hospitals of Başkent University between May 2008 and March 2013 were evaluated in terms of their demographic data, diagnosis weeks, concomitant anomalies and the course of their pregnancies. SPSS v. 16.0 was used for statistical calculations.
\end{abstract}

Results: The analysis of 61 pregnant women between 20 and 41 years old showed that it was the first pregnancy of $45.9 \%$ of them. Only $16.4 \%$ of them were at or over 35 years old. It was observed that $4.9 \%$ of them were conceived by assisted reproduction techniques. The rates of mild (10-12 mm), moderate (12.1-14.9 $\mathrm{mm}$ ) and severe ventriculomegaly $(\geq 15 \mathrm{~mm})$ were $65.6 \%, 24.7 \%$ and $4.8 \%$, respectively. Toxoplasma, Cytomegalovirus, Rubella or Herpes virus infections were not found in any case. Down syndrome was found in the karyotype analysis of 3 patients (4.9\%). The ventriculomegaly was unilateral in $67.2 \%$ of the cases. The detection rate between 16 and 24 weeks which were also the weeks for detailed ultrasonography was $52.5 \%$. There was an additional anomaly in $33.3 \%$ of the cases. The most frequent concomitant anomalies were found as increased nuchal thickness (13.3\%), corpus callosum agenesis (11.1\%) and nasal bone hypoplasia $(8.9 \%)$. In their follow-ups, it was observed that the findings were regressed in $53.8 \%$ of the cases, progressed in $19.3 \%$ of the cases and remained unchanged in $26.9 \%$.

Conclusion: When ventriculomegaly is detected, the presence of additional anomalies should be investigated by detailed ultrasonographic examination during etiological investigation. In the selective cases, the physicians may utilize the method of magnetic resonance imaging to evaluate additional cerebral anomalies. It is also necessary to recommend karyotype analysis and investigating Toxoplasma, Rubella, Cytomegalovirus and Herpes virus infections in the presence of additional anomaly and even in isolated cases regardless of the level of ventriculomegaly. Patients should be followed up regularly.

Keywords: Isolated ventriculomegaly, additional anomalies, followup.

\section{Özet: Ventrikülomegali vakalarının ultrasonografik değerlendirilmesi}

Amaç: Başkent Üniversitesi Adana ve Ankara Hastaneleri Perinatoloji bilim dalında tanı almış veya ventrikülomegali ön tanısı ile refere edilmiş hastaların demografik verilerinin retrospektif olarak değerlendirilmesi.

Yöntem: Bu çalışmada Mayıs 2008 ve Mart 2013 tarihleri arasında Başkent Üniversitesi Ankara ve Adana Hastaneleri Perinatoloji Bilim Dalına dışarıdan gönderilen veya kliniğimizde tespit edilen fetal ventrikülomegalisi olan 61 gebe demografik verileri, tanı konulma haftaları, eșlik eden anomaliler ve gebeliklerin seyri açısından değerlendirildi. İstatistiksel hesaplamalarda SPSS v. 16.0'dan faydalanild.

Bulgular: 20-41 yaş arası 61 gebenin değerlendirmesinde, $\% 45.9$ 'unun ilk gebelikleriydi. \% 16.4'ü 35 yaş ve üzeriydi. \%4.9'unun yardımcı üreme teknikleri ile gebe kaldığı izlendi. Hafif (10-12 mm), 1lımlı (12.1-14.9 mm) ve ciddi ventrikülomegali $(\geq 15 \mathrm{~mm})$ oranları sırası ile \%65.6, \% 24.7 ve \% 4.8 idi. Hiçbir vakada toksoplazma, sitomegalovirüs, rubella veya Herpes virüs enfeksiyonu saptanmadi. Karyotip analizinde 3 hastada Down sendromu tespit edildi (\%4.9). Ventrikülomegalilerin \%67.2'si tek taraflı idi. Ayrintılı ultrasonografi haftası olan 16-24 haftaları arası tespit oranı \%52.5 idi. \%33.3 ek anomali mevcuttu. En sık eşlik eden anomaliler sıklık sırasına göre artmış nukal kalınlık (\% 13.3), korpus kallozum agenezisi (\%11.1) ve nazal kemik hipoplazisi (\% 8.9) olarak izlendi. Takiplerde \%53.8 vakada bulguların gerilediği, \% 19.3'ünde ilerlediği ve \%26.9'unda değişmeden kaldığı izlendi.

Sonuç: Ventrikülomegali tespit edildiğinde etyoloji araştırmasında ayrıntılı ultrasonografik muayene ile ek anomalilerin varlığ araştırılmalıdır. Selektif vakalarda ek serebral anomalileri değerlendirmek için manyetik rezonans görüntüleme yönteminden faydalanılabilir. Karyotip analizi ve toksoplazma, rubella, sitomegalovirüs ve Herpes virüs enfeksiyonlarının araştırılması ek anomali varlığında ve hatta izole vakalarda ventrikülomegalinin derecesi ne olursa olsun önerilmelidir. Hastalar düzenli takibe alınmalıdır.

Anahtar sözcükler: İzole ventrikülomegali, ek anomaliler, takip.
Correspondence: Hakan Kalaycı, MD. Başkent Üniversitesi Tıp Fakültesi Kadın Hastalıkları ve Doğum Anabilim Dalı, Ankara, Turkey. e-mail: smartdr96@yahoo.com Received: April 15, 2014; Accepted: September 7, 2014

Please cite this article as: Kalaycı H, Özdemir H, Gülümser Ç, Parlakgümüş A, Çok T, Tarım E, Bilgin Yanık F. Ultrasonographic evaluation of ventriculomegaly cases. Perinatal Journal 2015;23(1):1-5.

(C2015 Perinatal Medicine Foundation
Available online at: www.perinataljournal.com/20150231001 doi: $10.2399 /$ prn.15.0231001 QR (Quick Response) Code:

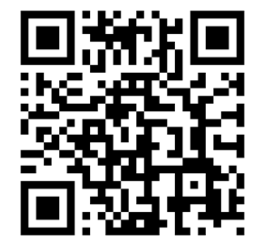




\section{Introduction}

The term ventriculomegaly (VM) is used for the cases where anterior horns of ventricle, cavum septum pellucidum and choroid plexus can be seen in the axial plane and lateral ventricle measurement on the plane is 10 $\mathrm{mm}$ and above at the glomus level of choroid plexus (Fig. 1). ${ }^{[1,2]}$ There are various definitions according to the width of lateral ventricle. When lateral ventricle measurements are $10-12 \mathrm{~mm}$ and $12.1-15 \mathrm{~mm}$, the definitions of mild and moderate $\mathrm{VM}$ are used. ${ }^{[3,4]}$ However, some authors deny $10-12 \mathrm{~mm}$ as mild VM and define mild VM as $10-15 \mathrm{~mm} \cdot{ }^{[5]}$ In measurements which are $15 \mathrm{~mm}$ and above, severe VM term is used. ${ }^{[6]}$ While mild VM prevalence is 7.9 out of 10,000 live births, severe VM prevalence is reported as 3.6 out of 10,000 live births. ${ }^{[7]}$

Many factors are assumed in the etiology such as infections; cerebral atrophy induced by white matter injury and/or cases causing absorption of cerebrospinal fluid to decrease; obstructive causes such as DandyWalker malformation or aqueductal stenosis; developmental anomalies such as encephalocele, corpus callosum agenesis (Figs. 2a and 2b); genetic disorders such as trisomy 13, 18 and 21; and cases such as choroid plexus papilloma which may cause excessive cerebrospinal fluid production. ${ }^{[8]}$ This expansion in ventricles may be accompanied by anomalies such as hydrocephaly, gray matter migration anomalies, corpus callosum agenesis, trisomies and microcephaly. ${ }^{[5]}$ The incidence of associated cerebral or extracerebral anomalies varies between $41 \%$ and $78 \% .{ }^{[2]}$ Many authors

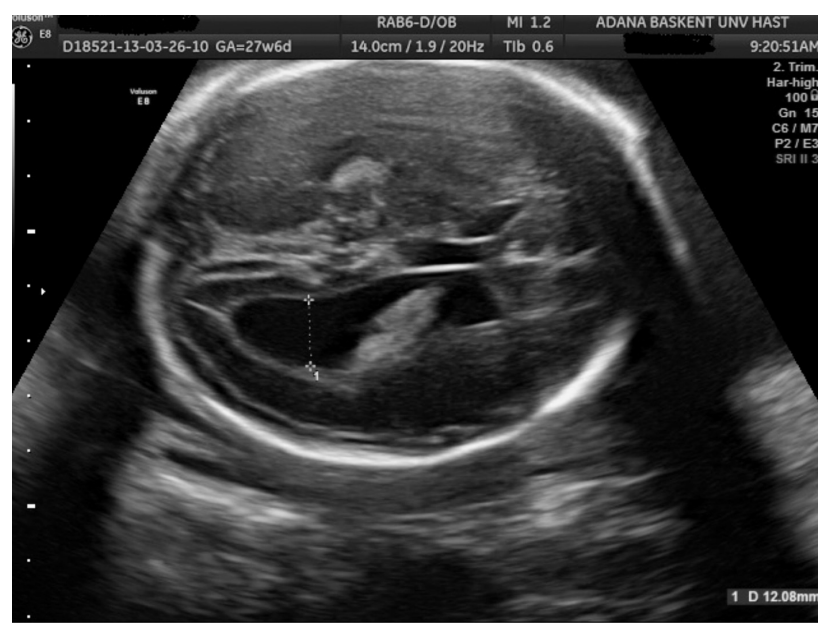

Fig. 1. Moderate ventriculomegaly.

believe that the presence of additional malformations is directly associated with the prognosis. Prognosis is observed better in most of the isolated VM cases. ${ }^{[2,9]}$ Therefore, prenatal diagnosis becomes crucial.

In this study, we aimed to analyze the demographic data, diagnosis weeks, concomitant anomalies and the course of pregnancy retrospectively in patients diagnosed with ventriculomegaly during intrauterine period.

\section{Methods}

In this study, 61 pregnant women with fetal ventriculomegaly diagnosed in our clinic or referred by other centers to the Perinatology Department of Ankara and
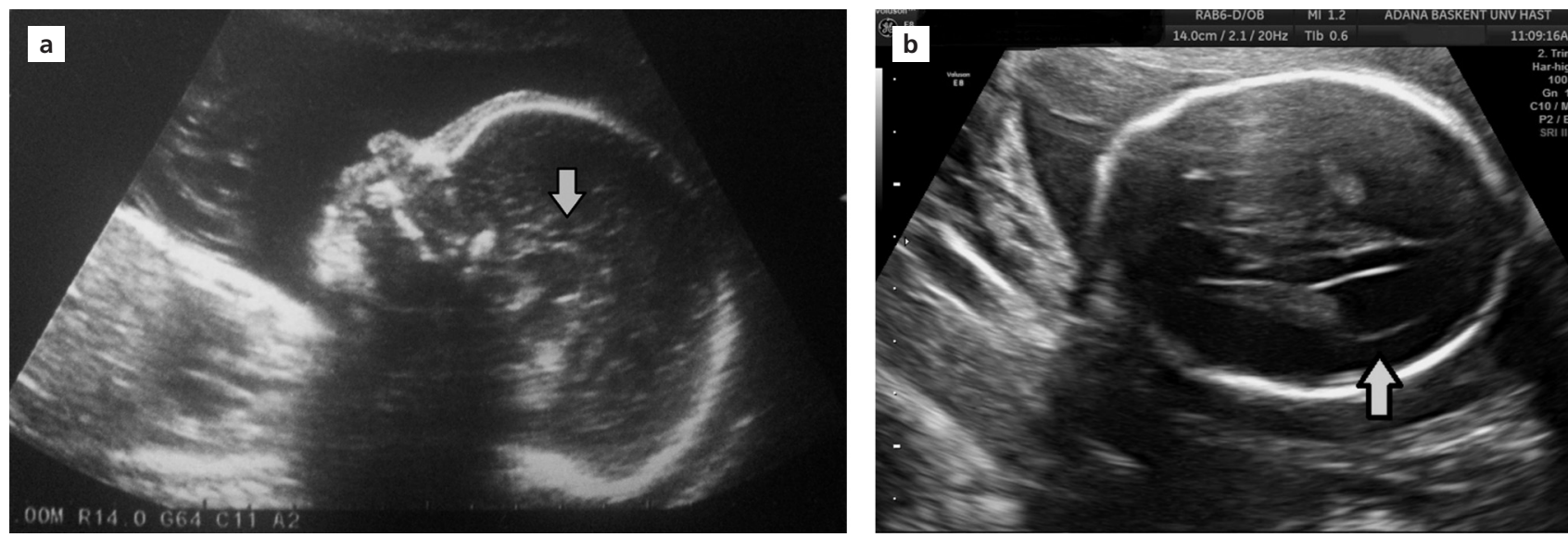

Fig. 2. (a) Corpus callosum agenesis (arrow). (b) Corpus callosum agenesis, colpocephaly, teardrop appearance (arrow). 
Adana Hospitals of Başkent University between May 2008 and March 2013 were evaluated in terms of their demographic data, diagnosis weeks, concomitant anomalies and the course of their pregnancies. All fetuses were evaluated by detailed fetal biometric examination. Statistical data were analyzed by SPSS v. 16.0 (SPSS Inc., Chicago, IL, USA) software.

\section{Results}

The analysis of 61 pregnant women between 20 and 41 years old showed that it was the first pregnancy of $45.9 \%$ of them. Only $16.4 \%$ of them were at or over 35 years old. It was observed that $4.9 \%$ of them were conceived by assisted reproduction techniques. The rates of mild (10-12 mm), moderate (12.1-14.9 mm) and severe ventriculomegaly ( $\geq 15 \mathrm{~mm}$ ) were $65.6 \%, 24.7 \%$ and $4.8 \%$, respectively. No Toxoplasma, Rubella, Cytomegalovirus (CMV) and Herpes virus infection was found in any of the pregnant women. Down syndrome was found in the karyotype analysis of 3 fetuses $(4.9 \%)$. The ventriculomegaly was unilateral in $67.2 \%$ of the cases. The detection rate between 16 and 24 weeks which were also the weeks for detailed ultrasonography was $52.5 \%$. The most frequent concomitant anomalies were observed as increased nuchal thickness $(13.3 \%)$, corpus callosum agenesis $(11.1 \%)$, and nasal bone hypoplasia (8.9\%). Additionally, obstetric magnetic resonance was applied to $44.3 \%$ of the pregnant women. Of pregnant women, $72.5 \%$ of them delivered at 37 weeks or later. In their follow-ups, it was observed that the findings were regressed in 53.8\% of the cases, progressed in $19.3 \%$ of the cases and remained unchanged in $26.9 \%$.

\section{Discussion}

In the detailed ultrasonographic examination performed on 18-22 weeks of gestation, it is routinely recommended to measure the width of lateral cerebral ventricles. ${ }^{[1,10,1]}$ In the lateral ventricle measurements, $10-12 \mathrm{~mm}$ is defined as mild VM, $12.1-15 \mathrm{~mm}$ as moderate and $15 \mathrm{~mm}$, and above as severe $\mathrm{VM}^{[3,4]}$

Infections may also have a role in the etiology. In the study of Dogan et al., severe VM was found in 5 of 8 cases with $\mathrm{CMV}$ infection, increased periventricular echogenicity, intracranial calcification in 4 cases, thalamic hyperechogenicity in 3 cases, and mega cisterna magna. ${ }^{[12]}$ Tijana et al. found VM, which did not display any finding on previous weeks, in patient with positive toxoplasmosis at 25 weeks of gestation. ${ }^{[13]}$ Dommergues et al. detected CMV positivity in $29 \%$ of the cases in their study. ${ }^{[14]}$ In various publications, infection positivity was observed as $10-20 \%$ in severe VM cases while it was $1-5 \%$ in mild VM cases. ${ }^{[9,15,16]}$ Therefore, it is recommended to evaluate all cases diagnosed with VM in terms of infection. ${ }^{[6,15,17,18]}$ In our study, no infection factor was found; the reason is the rate of severe VM seen in our patients as low as $4.8 \%$.

Chromosomal anomaly incidence varies in VM cases between $0 \%$ and $14 \% \cdot{ }^{[5,6,15]}$ In our study, Down syndrome was found in $4.9 \%$ (3) cases. While Nicolaides et al. reported chromosomal anomaly incidence as 3\% in isolated VM cases, they showed this rate as $36 \%$ in the presence of additional anomaly. Also, aneuploidy was reported at a low rate in isolated severe VM cases compared to isolated mild VM cases. ${ }^{[19]}$ Similarly, Melchiorre et al. reported the rate of chromosomal anomaly in isolated cases as $2.8 \% .^{[20]}$ Gaglioti et al. did not find any chromosomal anomaly in severe VM cases while aneuploidy rate was $3.5 \%$ in mild and moderate VM cases. ${ }^{[16]}$ Gezer et al. reported chromosomal anomaly incidence $(6.8 \%)$ in fetuses with severe ventriculomegaly higher than the fetuses with mild ventriculomegaly (4.2\%). Chromosomal anomaly incidence $(8.6 \%)$ in fetuses with isolated ventriculomegaly was also found higher than those with additional anomaly $(3.8 \%))^{[21]}$ Sezik observed Type 2 triploidy case with VM accompanied by atrioventricular septal defect. ${ }^{[2]}$ Kara described the association of VM and 47 XXY syndrome in a case report. ${ }^{[23]}$

In ventriculomegaly cases, it is possible to observe both cerebral and extracerebral malformations as an additional anomaly. They especially accompany with severe VM. The most frequent concomitant anomalies of severe VM cases are corpus callosum agenesis and bifid spine. ${ }^{[24,25]}$ In mild and moderate VM cases, this rate varies between $10 \%$ and $76 \% \cdot{ }^{[17,26]}$ Various studies reported additional anomaly incidence at rates reaching up to $50 \% .^{[6,11,15]}$ Gaglioti et al. found additional anomaly in $60 \%$ of severe VM cases. In $88 \%$ of these cases, families preferred to terminate the pregnancy. ${ }^{[16]}$ Tatli et al. found additional anomaly in 9\% of cases with $10-15 \mathrm{~mm}$ ventricle width. ${ }^{[27]}$ In our study, the most frequent additional anomalies (33.3\%) were increased nuchal thickness (13.3\%), corpus callosum agenesis $(11.1 \%)$ and nasal bone hypoplasia $(8.9 \%)$. 
We observed in our study that the findings were regressed in $53.8 \%$ of the cases, progressed in $19.3 \%$ of the cases and remained unchanged in $26.9 \%$. Ouahba et al. reported regression in $11 \%$ of 167 mild VM cases, and they observed more regression in these cases in terms of neurological development. ${ }^{\left[{ }^{[]}\right.}$ Melchiorre et al. found a progression at a rate of $15.7 \%$. In those with progression, there was poor prognosis in terms of neurological development and association with chromosomal anomalies. ${ }^{[20]}$

During magnetic resonance imaging, Levine et al. found additional findings at a rate of $13.5 \%$ which may change patient management in cases found to have anomaly by ultrasonography. ${ }^{[28]}$ Gezer et al. asserted that ventricle width and brain parenchyma volume rate may be helpful to determine prognosis in magnetic resonance imaging. Parenchyma volumes of those with poor prognosis were found to be low. ${ }^{[29]}$ We applied obstetric magnetic resonance imaging to $44.3 \%$ of our cases. We confirmed the diagnosis of corpus callosum agenesis in four fetuses by ultrasonography, cortical atrophy in one case, and encephalomalacia in one case. In line with these findings, magnetic resonance imaging is significant to confirm the suspected diagnoses established by ultrasonography. The use of magnetic resonance imaging is useful for pathologies such as neuronal migration disorders, delayed sulcation, gyrus formation and heterotopias which can be detected at late second and third trimesters and overlooked by ultrasonography. ${ }^{[30,31]}$

After the 11 years of follow-up of 101 children with isolated VM, normal psychomotor development was observed in 89 of them, and neurological disorder in the spectrum reaching out from language delay up to the severe mental retardation. ${ }^{[12]}$

Vergani et al. found neurological development retardation clearly lower in groups with $12 \mathrm{~mm}$ and lower widths than the group with $12 \mathrm{~mm}$ and above (3\% vs. $23 \%) \cdot{ }^{[6]}$ Devaseelan et al. reported neurological development retardation as $14 \%$ in children with progressed VM during intrauterine period. ${ }^{[32]}$ In another study, scores below the normal levels were reported for fine motor skills and language development in children with persisting ventricle width during prenatal period. ${ }^{[33]}$

\section{Conclusion}

When ventriculomegaly is detected, the presence of additional anomalies should be investigated by detailed ultrasonographic examination during etiological investigation. In the selected cases, the physicians may utilize the method of magnetic resonance imaging to evaluate additional cerebral anomalies. In line with the current information we have, we recommend performing karyotype analysis and investigating Toxoplasma, CMV and infections such as Rubella regardless of the level of ventriculomegaly and even in the isolated ventriculomegaly cases without any additional anomaly. Patients should be followed up regularly. The parents should be informed in detail for the neuropsychiatric conditions that may arise during postpartum period.

Conflicts of Interest: No conflicts declared.

\section{References}

1. International Society of Ultrasound in Obstetrics and Gynecology Education Committee. Sonograpic examination of the fetal central nervous system: Guidelines for performing the "basic examination" and the "fetal neurosonogram". Ultrasound Obstet Gynecol 2007;29:109-16.

2. Cardoza JD, Goldstein RB, Filly RA. Exclusion of fetal ventriculomegaly with a single measurement: the width of the lateral ventricle atrium. Radiology 1988;169:711-4.

3. Signorelli M, Tiberti A, Valseriati D, Molin E, Cerri V, Groli $\mathrm{C}$, et al. Width of fetal lateral ventricular atrium between 10 and $12 \mathrm{~mm}$ : a simple variation of the norm? Ultrasound Obstet Gynecol 2004;23:14-18.

4. Wax JR, Bookman L, Cartin A, Pinette MG, Blackstone J. Mild fetal cerebral ventriculomegaly: diagnosis, clinical associations, and outcomes. Obstet Gynecol Surv 2003;58:40714.

5. Bromley B, Frigoletto FD Jr, Benacerraf BR. Mild fetal lateral cerebral ventriculomegaly: clinical course and outcome. Am J Obstet Gynecol 1991;164:863-7.

6. Vergani P, Locatelli A, Strobelt N, Cavallone M, Ceruti P, Paterlini G, et al. Clinical outcome of mild fetal ventriculomegaly. Am J Obstet Gynecol 1998;178:218-22.

7. Sethna F, Tennant PWG, Rankin J, C Robson S. Prevalence, natural history, and clinical outcome of mild to moderate ventriculomegaly. Obstet Gynecol 2011;117:86776.

8. McKechnie L, Vasudevan C, Levene M. Neonatal outcome of congenital ventriculomegaly. Semin Fetal Neonatal Med 2012;17;301-7.

9. Ouahba J, Luton D, Vuillard E, Garel C, Gressens P, Blanc $\mathrm{N}$, et al. Prenatal isolated mild ventriculomegaly: outcome in 167 cases. BJOG 2006;113:1072-9.

10. American College of Obstetricians and Gynecologists (ACOG). Ultrasonography in Pregnancy: ACOG Technical Bulletin 187. Washington, DC: ACOG; 1993. 
11. American Institute of Ultrasound in Medicine. AIUM Practice Guideline for the performance of an antepartum obstetric ultrasound examination. J Ultrasound Med 2003; 22:1116-25.

12. Dogan Y, Yuksel A, Kalelioglu IH, Has R, Tatlı B, Yildirim A. Intracranial ultrasound abnormalities and fetal cytomegalovirus infection: report of 8 cases and review of the literature. Fetal Diagn Ther 2011;30:141-9.

13. Zivkoviç T, Ivoviç V, Vujaniç M, Klun I, Bobiç B, Nikoliç A, et al. Adverse fetal outcome in the absence of timely prenatal diagnosis of congenital toxoplasmosis. Wien Klin Wochenschr 2011;123;43-6.

14. Dommergues M, Mahieu-Caputo D, Fallet-Bianco C, Mirlesse V, Aubry MC, Delezoide AL, et al. Fetal serum interferon-alpha suggests viral infection as the aetiology of unexplained lateral cerebral ventriculomegaly. Prenat Diagn 1996;16:883-92.

15. Pilu G, Falco P, Gabrielli S, Perolo A, Sandri F, Bovicelli L. The clinical significance of fetal isolated cerebral borderline ventriculomegaly: report of 31 cases and review of the literature. Ultrasound Obstet Gynecol 1999;14:320-6.

16. Gaglioti P, Danelon D, Bontempo S, Mombrò M, Cardaropoli S, Todros T, et al. Fetal cerebral ventriculomegaly: outcome in 176 cases. Ultrasound Obstet Gynecol 2005;25:372-7.

17. den Hollander NS, Vinkesteijn A, Schmitz-van Splunder P, Catsman-Berrevoets CE, Wladimiroff JW. Prenatally diagnosed fetal ventriculomegaly: prognosis and outcome. Prenat Diagn 1998;18:557-66.

18. Pilu G, Hobbins JC. Sonography of fetal cerebrospinal anomalies. Prenat Diagn 2002;22:321-30.

19. Nicolaides KH, Berry S, Snijders RJM, Thorpe-Beeston JG, Gosden C. Fetal lateral cerebral ventriculomegaly: associated malformations and chromosomal defects. Fetal Diagn Ther 1990;5:5-14.

20. Melchiorre K, Bhide A, Gika AD, Pilu G, Papageorghiou AT. Counseling in isolated mild fetal ventriculomegaly. Ultrasound Obstet Gynecol 2009;34:212-24.

21. Gezer C, Ekin A, Özeren M, Taner CE, Özer Ö, Koç A, et al. Fetal serebral ventikülomegalide kromozomal anomali sıklı̆̆ı. Perinatoloji Dergisi 2013;21 Suppl 1:S32.
22. Sezik M. Ventrikülomegali ve atriyoventriküler septal defekt: Tip 2 triploidi. Perinatoloji Dergisi 2013;21 Suppl 1:S39.

23. Kara M. Prenatal 47 XXY sendromu ve ventrikülomegali birlikteliği: Vaka sunumu. Bozok Tip Dergisi 2012;1:53-6.

24. Breeze ACG, Alexander PMA, Murdoch EM, MissfelderLobos HH, Hackett GA, Lees CC. Obstetric and neonatal outcome in severe ventriculomegaly. Prenat Diagn 2007;27: 124-9.

25. Morris JE, Rickard S, Paley MNJ, Griffiths PD, Rigby A, Whitby $\mathrm{EH}$. The value of in-utero magnetic resonance imaging in ultrasound diagnosed foetal isolated cerebral venticulomegaly. Clin Radiol 2007;62:140-4.

26. Romero R, Pilu G, Jeanty P, Ghidini A, Hobbins JC. The central nervous system. Prenatal Diagnosis of Congenital Anomalies. East Norwalk, CT: Appleton \& Lange; 1988. p. $1-79$.

27. Tatlı B, Özer I, Ekici B, Kalelioğlu I, Has R, Eraslan E, et al. Neurodevelopmental outcome of 31 patients with borderline fetal ventriculomegaly. Clinical Neurol Neurosurg 2012; 114;969-71.

28. Levine D, Barnes PD, Robertson RR, Wong G, Mehta T. Fast MR imaging of fetal central nervous system abnormalities. Radiology 2003;229:51-61.

29. Gezer NS, Güleryüz H, Gezer C, Koçyiğit A, Yeşilırmak $\mathrm{CD}$, Güçlü S, et al. Fetal manyetik rezonans görüntüleme ile yapılan beyin hacim ölçümlerinin ventrikülomegali ile ilişkisi. Perinatoloji Dergisi 2013;21 Suppl 1:S35.

30. Benaceraf BR, Shipp TD, Bromley B, Levine D. What does magnetic resonance imaging add to the prenatal sonographic diagnosis of ventriculomegaly? J Ultrasound Med 2007;26: 1513-22.

31. Manganaro L, Savelli S, Francioso A, Di Maurizio M, Coratella F, Vilella G, et al. Role of fetal MRI in the diagnosis of cerebral ventriculomegaly assessed by ultrasonography. Radiol Med 2009;114:1013-23.

32. Devaseelan P, Cardwell C, Bell B, Ong S. Prognosis of isolated mild to moderate fetal cerebral ventriculomegaly: a systematic review. J Perinat Med 2010;38:401-9.

33. Lyall AE, Woolson S, Wolfe HM, Goldman BD, Reznick JS, Hamer RM, et al. Prenatal isolated mild ventriculomegaly is associated with persistent ventricle enlargement at ages 1 and 2. Early Hum Dev 2012;88;691-8. 